\title{
PALAVRA E(M) MOVIMENTO: FORMAS VOCAIS EM ALDEIAS GUARANI
}

\author{
Elizabeth Pissolato ${ }^{1}$ \\ ${ }^{1}$ Universidade Federal de Juiz de Fora, MG, Brasil
}

\section{Introdução}

Em uma manhã de abril de 2002 na aldeia Araponga, Ilda, uma mulher muito afeita à conversa e às brincadeiras, lançou para mim e sua filha Marina uma charada: o que, sem sair do lugar, rodaria o mundo inteiro? Passa as mãos sobre seu próprio rosto e a filha responde: "Xe ayvu, a palavra" (ou propriamente: o que falo). Dias antes comentava sobre ter as mãos doloridas certa vez, de modo que não conseguia sequer manobrar o burro ou amarrar um embrulho em sua ida até uma vila próxima à aldeia, e seu pai teria então lhe dito na volta: "Alguém já falou mal (ijayvu vai) lá longe", "a voz já veio" (fazendo machucar a mão de Ilda)².

Eventos como este, mas também a constatação, durante os anos de pesquisa de campo, de um grande investimento em formas bonitas de falar, desde contextos aparentemente simples de conversa a narrativas sobre um tempo antigo e falas bonitas feitas em rituais, nos levam à questão do que fazem as palavras.

Pronunciadas ou não, elas parecem cruciais na produção da vida e do parentesco ou quando se trata de negá-lo - pela fofoca ou feitiçaria. No âmbito da pessoa, a palavra define a própria condição de quem vive. A alma-palavra ou nhe'ë, princípio que vem se juntar à pessoa que nasce, é o que a levanta e faz caminhar na Terra, sem o que ela não ficaria entre os vivos. Se, por um lado, este princípio-palavra garante a comunicação com o mundo divino e define um estatuto especial de humanidade (eleita) aos Guarani, por outro lado, é a palavra, que toma forma propriamente enquanto fala, cujo papel é crucial na construção das relações entre humanos. Podemos dizer que o investimento nessas relações coloca em primeiro plano agenciamentos-com-palavras que vão desde a comunicação que se faz "mentalmente" com crianças pequenas até a prática de aconselhar ou instruir fazendo menção à vida dos antigos. Das trocas cotidianas de palavras 
brandas às falas emocionadas na casa ritual, o trato entre parentes envolve sempre, pode-se dizer, uma arte da palavra. Palavras, enfim, podem se tornar potentes conectando-se com certos sentimentos, emoções, com a fumaça do tabaco, os instrumentos, a música.

Destoando de uma abordagem da palavra que se tornou clássica na literatura sobre grupos guarani, levando-a à sua definição como fundamento doser(Cadogan 1959; Chamorro 1995, 1998, entre outros) e a interpretações da pessoa e do ritual nos termos de uma "religiosidade guarani"3, este texto busca aproximações com dimensões como: o cuidado no falar cotidiano (para evitar violência e cisões); a palavra como instrumento do cuidado (terapêutico) entre parentes (que contam, narram); o "falar bem" que leva consigo outras pessoas (constituindo corpos-coletivos); a palavra (e)levada a canto, intensificada no corpo, na dança ${ }^{4}$.

O texto que segue busca, assim, menos uma resposta sobre o "que vem a ser a palavra guarani" e mais sobre o que ela faz, ou sobre como a palavra ganha força em diferentes contextos em que é agenciada.

\section{Conversar}

Um dos modos de maior investimento para a produção de parentesco entre grupos ameríndios é a conversa ${ }^{5}$ e nas aldeias mbya não é diferente. A oferta do $k a^{\prime}$ a (erva-mate) quando se chega em uma casa ou no despertar dos que partilham um mesmo pátio em reunião matinal à volta do fogo é sempre um convite à conversa.

O que se espera nesses contextos de interação é um clima pacífico, ameno, e o modo de falar é absolutamente importante para conquistá-lo. A dimensão estética para a qual Joana Overing (1991) chamou a atenção ao tratar da "convivialidade amazônica" (Overing \& Passes 2000) é marcante nas aldeias guarani. Há um investimento importante para se falar bem e de forma bonita. A fala deve ser branda e livre de qualquer aspereza. Não deve de forma alguma tornar-se fala impositiva, voz de comando. Mesmo as pessoas em posição de autoridade não devem levantar a voz, sob o risco de produzir antipatias e ver seus parentes indo embora.

Nas conversas cotidianas, o humor é também um componente importante. Cria interesse e diverte, fazendo agradável a convivência. Encontros fortuitos numa trilha entre casas podem ser bons momentos para brincar com as palavras.

A arte nas conversas, de todo modo, não deixa de ser uma espécie de jogo entre falar e não falar. Assim, fala-se de coisas amenas de modo brando 
para não se falar de outras coisas (e) de outro modo. Com isso quero sugerir que, no final das contas, o cuidado no falar se liga ao controle da violência, ponto que passo a desenvolver.

Para começar, é fundamental perceber o aspecto de mão dupla na fala. Há sempre duas perspectivas (ou mais) envolvidas num ato de fala: a de quem fala e a de quem escuta, e ambas as perspectivas estão implicadas no que a fala produz. Sim, a fala pode desdobrar-se em sentimentos de bem-estar, satisfação, boa disposição ou, inversamente, em sensações de desconforto, em antipatia, indisposição, sendo sempre relacional. Afinal, ainda que se mantenha a atenção aos valores éticos do comedimento na fala não excessiva, ainda que se escolham as melhores palavras, nunca se sabe efetivamente como estas serão ouvidas. Há sempre um risco na comunicação interpessoal.

Dizendo de outra maneira, há uma invisibilidade nos processos relacionais que se juntam à materialidade da fala e que certamente produz efeitos sobre as pessoas, seus estados físico-emocionais. As antipatias colocam sob suspeita a fala/o fazer dos outros, assim como males instalados no corpo (doença [mba'eaxy] de modo geral). Enfim, a indisposição própria traz alguma desconfiança sobre a disposição de outras pessoas que participam daquele convívio.

Até aqui observamos que a fala não se separa de processos pessoais - como adoecimento ou produção de saúde - os quais não são afinal outra coisa que efeitos das relações. A força das palavras aqui implica expressão vocal e escuta; materialidade e incerteza sobre o "que não se vê (-exa e'ÿ va'e) ou se escuta, mas pode vir se juntar à palavra. Podemos afirmar, assim, que o uso de certas palavras - particularmente a pronúncia do nome pessoal ${ }^{6}$ produz efeitos em seu portador. Desta forma, seria no "fortalecimento" de uma criança chamada por seu nome "verdadeiro" (divino) pelos parentes que a recebem na Terra; e assim também seria para o enfraquecimento ou mesmo a morte por feitiçaria de alguém que tem, junto com seu nome pronunciado, alguma doença soprada. Mas nestes e noutros usos, de todo modo, os efeitos da palavra não seriam definitivos, pois há sempre conexões possíveis nesses percursos de saúde e doença, há sempre possibilidades de alteração dos estados pessoais nos mundos altamente transformacionais ameríndios.

A força da palavra aqui não parece estar (completamente) nela mesma, nem caberia restringi-la à intencionalidade de quem fala. De todo modo, não vemos entre os Mbya uma ontologia de forças como aquela descrita por Magnus Course para os Mapuche, em que [...] o falado [teria] uma ligação apenas tênue com a intencionalidade do falante [...] [já que se encontra] saturado de uma força autônoma que lhe pertence, [força esta] 
em continuidade com uma ontologia de forças que é constitutiva do mundo indígena" (Course 2011:782).

O caráter marcadamente relacional da palavra mbya aparece na ênfase dada não apenas ao modo "bom" (e/ou "bonito") de falar, mas também à importância de "não ligar" para falas que poderiam produzir mal-estar ou antipatia: "-ikorive" ("viver/estar sem preocupação") é uma das maneiras de referência à atitude de quem não se deixa ferir por falas descuidadas de outrem.

É possível reconhecer nas aldeias mbya, de um lado, modos mais ou menos agressivos de uso da palavra, que vão desde a fala descuidada à fofoca (ayvuxe) e à fala feiticeira (-jayvu vai, "fala feia") feita com intenção de fazer mal a alguém. Por outro lado, quando passarmos ao polo da produção de parentesco, veremos que práticas de "contar" (-mombe'u), aconselhar (-mongeta), ou mesmo "benzer" (-vëjë) com palavras ocupam lugar central na experiência de viver entre parentes, muitos homens e mulheres adultos tornando-se habilidosos nelas.

Voltando ao tema do comedimento na fala e do controle da agressividade, lembro aqui de uma sugestão que fiz em outro momento (Pissolato 2007) que me parece dar o tom da boa medida no falar. Não se deve ser excessivo, como já observado, ponto constantemente criticado no comportamento dos brancos (jurua), que falariam demasiadamente. Deve-se evitar imposições na fala, ou rudeza. Por outro lado, não cabe abster-se da palavra quando algum parente vem lhe "contar" algo (de si) como um sonho, uma impressão, algo que sente ou pressente. Neste caso, não caberia "não ligar", o que seria tido como falta de cuidado, descaso da parte de quem ouve. Aqui já nos aproximamos de um modo de fala (e escuta) a ser abordado adiante. Mas cabe ainda explorar um aspecto importante desse jogo ético e político entre o falar e o não falar que presenciamos nas aldeias.

Um modo nada incomum de abandono de um lugar e, muitas vezes, de um cônjuge é o que é referido como "fugir" (-java). Homens e mulheres costumam lançar mão desta maneira de "sair sem falar", e são diversos os desdobramentos possíveis desses eventos, tanto em termos práticos quanto físico-emocionais. Em trabalho anterior (Pissolato 2015)apresentei uma breve etnografia sobre fugas, e neste momento interessa-me principalmente destacar o aspecto da ausência de palavras aí.

Saídas para visitas a outras aldeias são normalmente objeto de muita conversa e planejamento. Costumam ser precedidas de alguns dias de reza na opy (a casa ritual que reúne pessoas para a reza à noite nas aldeias), havendo sempre certa apreensão sobre "o que pode acontecer" a quem vai ou fica. Parentes que ficam sabem os planos de quem vai e a data do retorno. 
É possível que algumas pessoas - especialmente jovens não casados ou quem tenha parentes na aldeia de destino - se juntem ao grupo de viajantes justamente na expectativa de permanecer, caso se "alegrem" na área visitada (Pissolato 2007:122-223). Mas viajantes que se encontram engajados de modo mais efetivo em relações de parentesco e afinidade na aldeia de onde partem partilham os preparativos com os que ficam, como foi dito, e voltam para estes com as notícias ou mesmo com algum morador da aldeia visitada que se anime a vir junto.

De início, o sair sem falar parece estar no polo oposto ao modo de agir entre parentes: nega-se a relação, sem explicação, sem tentativa de conciliação, sem palavras. Mas há complexidades. E aqui novamente é a dimensão processual que merece atenção. Muitas agressões invisíveis, notadamente a feitiçaria detectada como causa de doenças persistentes que os xamãs tratam em sessões do ritual da reza-canto na opy resultam, conforme eles diagnosticam, de agressões de ex-parceiros ou parceiras de casamentos passados. Ainda, uma das maiores evitações na vida cotidiana é a da "raiva", do "encolerizar-se", que pode levar à agressão física e ao homicídio. Não falar nessas circunstâncias pode ser, assim, uma maneira de controlar - ainda que não completamente - a violência.

Voltando ao contexto das visitas entre aldeias, é interessante notar, especialmente no caso de visitantes prestigiosos como líderes de uma localidade e xamãs reconhecidos, mas também no caso de outros adultos dedicados aos modos cerimoniosos de fala, uma forma de "saudar" (-xarura) os anfitriões em que o/a visitante conta em detalhes seu percurso até ali, desde o lugar de que saiu, onde dormiu, do que se alimentou até a sua chegada.

Course (2011:790-793) descreve, entre os gêneros de fala mapuche, o chamado nutramtun, que compreende a "declamação da história de vida e genealogia" por alguém, e ainda o amüllpullün, discurso também de caráter biográfico feito especialmente no contexto do funeral de uma pessoa, como "forma de completar (dewman) o saber sobre o defunto e permitir a partida de seu espírito". Tais gêneros demonstram como, na visão dos Mapuche, a fala é um meio privilegiado quando se trata de uma pessoa saber sobre outra.

A "saudação" mbya acima mencionada, feita geralmente na opy da aldeia visitada, não deixa de estar voltada para o fazer-se conhecer. Trata-se, a meu ver, justamente de evitar desconfianças que poderiam ser lançadas sobre o visitante. Dizer como chegou e a que veio marcam sua intenção pacífica, exposta em fala demorada para quem venha até a casa ouvi-la. Esta prática não deixa de lembrar os rituais amazônicos de chegada de visitantes, como, por exemplo, o tasànomaama candoshi(Surrallés 2003) e o wayamou yanomami (Kelly 2017) e as transformações que operam para 
o estabelecimento de vínculos sociais com aquele que seria potencialmente inimigo ou de status ambíguo, a partir do que pode haver trocas com mutualidade. É certo, contudo, para o caso mbya, que, tal qual pensariam os Mapuche, resta alguma "opacidade das pessoas", que se revelará efetivamente nas relações entre visitantes e seus anfitriões na prática. Apresentar-se na chegada, com uma fala feita para todos (que se interessem em ouvi-la) opõe-se ao sair sem falar e, neste sentido, funcionaria justamente como um aceno da intenção de agir como parente, isto é, de uma maneira capaz de produzir bem-estar.

Antes de passar aos modos mais investidos e elaborados de uso da palavra na produção de parentesco, gostaria de marcar de maneira mais sistemática a associação entre falar e sair. Se falar o nome da criança, a socialização na conversa branda, as formas de saudar e explicitar as próprias intenções se voltam para o que as pessoas entendem como "ficar bem" ou "viver bem", -ikoporã , boa parte dos "maus-feios" efeitos de fala - nem sempre explicitados - produzem saídas. Como foi dito anteriormente, o estado de indisposição ou mal-estar já colocaria suspeitas sobre antipatias e outros "malfeitos". Por sua vez, "fofocas" (ayvuxe) estão efetivamente na origem de muitas saídas não apenas de uma ou outra pessoa, mas frequentemente de grupos familiares, correspondendo por vezes a cisões importantes no interior de um coletivo que vivia junto até então. Falas agressivas ditas por alguém, falas traduzidas como "mandar embora", falas que podem estar escondendo feitos agressivos, todas elas tendem a fazer sair. Noutras palavras, parece que nas aldeias mbya sair é sempre uma solução mais interessante para dar fim a contextos em que não se está bem ou não se fica (mais) alegre.

\section{Contar}

Se a articulação entre palavra e movimento pode ser tomada para uma abordagem do controle da violência como vimos até aqui, no outro polo, ela daria forma à própria relação de parentesco, que podemos, então, definir em boa medida como aquela de seguir, acompanhar ou "ir atrás" de um parente (Pissolato 2007).

O movimento como forma-efeito da relação de parentesco é objeto que merece atenção desde as primeiras investidas para se fazer de alguém parente. Muitas etnografias sobre grupos Guarani chamaram a atenção para o cuidado que pais de crianças pequenas devem ter ao se afastarem de casa, de modo a sinalizar o caminho tomado para que a alma, o nhe'ë da criança, não se perca, por exemplo, no mato, ao ir atrás do pai. Osvaldo, que conheci em Mangueirinha e nos acompanhou em viagem até Parati Mirim, 
no Rio de Janeiro, comentou que "conversara mentalmente" com seu filho pequeno quando estava saindo da aldeia, contando para ele o que iria fazer para que ficasse tranquilo e nada (de ruim) lhe acontecesse ${ }^{7}$.

Desde esse momento, o aprendizado da convivência com parentes não deixará de ser um exercício de seguir a fala e os deslocamentos de alguém ${ }^{8}$, fórmula que estaria na base da "liderança social" dos pajés-principais (Nimuendaju 1985:75) ou antigos ñanderu (cf Schaden 1962:99-106) e orientaria os movimentos migratórios em busca da "Terra sem Mal"9. Seguir as palavras promissoras de um xamã, andar junto com ele em busca do lugar que anteviu em sonho, seguir sua reza-canto, tudo isto compõe o tema clássico do profetismo e das migrações tupi-guarani (Métraux 1927; H.Clastres 1978 [1975]).

Como afirmei anteriormente (Pissolato 2007), há muitas complexidades aqui, tanto no que diz respeito ao processo de constituição de posições de liderança no seio de um coletivo que vive-anda junto (o qual remete ao tema correlato na etnologia ameríndia da autonomia pessoal), quanto na abordagem do parentesco mbya em sua multilocalidade, que nos exige ampliar o horizonte para definir o que vem a ser o parentesco ou a experiência de viver entre parentes.

Mas neste momento gostaria de concentrar o olhar (melhor dizendo, a escuta) especialmente em modos de fazer a fala para parentes. Se, no item anterior, observávamos o cuidado no falar, aqui quero tratar de uma fala que é em si mesma (instrumento de) cuidado. Fala mais ou menos elaborada que conta e instrui, que "coloca na cabeça [de quem escuta]" (-moïiakã) histórias que serão muitas vezes ouvidas e mais tarde também contadas, sabedorias diversas como aquelas dos "antigos" que foram ouvidas de avós, narrativas que sempre criam um interesse especial - de quem pára para escutar - na audiência ${ }^{10}$.

Como demonstrou Peter Gow (1997:45), o contar e o ouvir "histórias dos antigos" surgem como momentos privilegiados na constituição do parentesco. Entre os Piro, trata-se de um contexto especial de expressão de nshinikanchi ("mente, inteligência, memória, respeito, amor"). Buscando levar em conta o papel constitutivo da subjetividade no parentesco, o autor observa que tanto quem conta quanto quem escuta a narrativa manifestam nshinikanchi, esta capacidade fundadora da "consciência" do parentesco.

De modo geral, podemos dizer que parentes mbya contam (-mombe' $u$ ) entre si o que se passa com eles: como se sentem, o que viram em sonho (-exara' $u$ ), o que experimentaram e souberam em visitas a outras aldeias etc. Mas refiro-me aqui de modo especial ao contar que também é comentado como uma fala que "passa conhecimento". 
Este uso da palavra implica uma assimetria geracional. São os velhos e as velhas efetivamente que sabem contar, o que envolve não só um acúmulo pela memória (as narrativas do mito de Kuaray, por exemplo, tendem a ser mais detalhadas quando feitas pelos mais velhos), mas também o domínio da forma: na voz dos mais velhos, a história é contada com certo ritmo e entonação característicos.

O ponto nos lembra o comentário de Carlos Fausto (2001:219) sobre a chefia entre os Parakanã. Conforme o autor, a posição do chefe se baseia tanto na capacidade de memorizar ou "conter conhecimento", quanto de transmiti-lo: "Para ser um continente de gente é preciso conter conhecimento e animá-lo pelo fluxo de palavras".

Entre os Mbya, há um caminho de aprendizado ao longo da vida até se chegar à condição de quem é capaz de "passar (sua) sabedoria" oralmente. A fala tende, assim, a se elaborar em conteúdo e forma quando proferida pelos que são referidos como "nhanderamoi" e "nhandejaryi", "nosso avô" e "nossa avó" respectivamente.

Nem sempre me parece possível distinguir com clareza gêneros de fala específicos aqui, ou perceber com nitidez as fronteiras entre uma fala que instrui sobre os ("bons-bonitos") costumes dos antigos - em matérias como o casamento, maneiras de cuidar das crianças, a alimentação etc e a chamada "fala da opy", modo de fala através de imagens poéticas que faz uso de um vocabulário específico (a "língua de nhanderu"), de conhecimento restrito, e que tematiza aspectos do mundo divino e da relação entre os Guarani e este mundo. Feitas sempre na opy, a casa onde se reza, canta e se cura com tabaco, mas que também acolhe reuniões com a presença de pessoas de outras aldeias e de brancos visitantes, essas falas elaboradas são acompanhadas por movimentos corporais do orador ou oradora, passos regulados no ritmo da voz, caminhando-se de um lado a outro em frente ao grupo de ouvintes que permanece sentado, vez ou outra exclamando, em apoio, "Anhete" ("[isso] é verdadeiro").A habilidade aqui se expressa no gesto e na fluidez da palavra, feita em discursos encadeados que podem durar horas, em sessões que entremeiam a reza-canto em períodos rituais ou em contextos cerimoniais que reúnem num mesmo local homens e mulheres de diferentes lugares, reconhecidos em sua "sabedoria", os quais se revezam nessas performances.

Voltando ao par escutar e falar, notamos que a escuta do que contam os mais velhos é a condição primeira de produção de conhecimento ou sabedoria, isto é, capacidades-saberes necessários para se viver bem. Assim como entre os Parakanã, é preciso saber escutar, guardar na cabeça o que foi contado. Trata-se aqui, como lá, me parece, de “[...] uma física da presença, 
de uma impregnação auditiva das narrativas contadas repetidas vezes" (Fausto 2001:222). Como disse Davi Kopenawa (2015 [2010]:376) para os Yanomami, quando se é jovem, "[o] pensamento é cheio de esquecimento [só muito mais tarde sendo possível] tomar dentro de si as palavras dos antigos".

Nem todos os homens e mulheres mbya mais velhos desenvolvem a habilidade na oratória ou investem neste modo elaborado de aconselhar (-mongeta). Por outro lado, outras formas de liderança se construiriam igualmente sobre um aprendizado da fala. Lembro-me de Nírio, que ao assumir o posto de professor e liderança na aldeia de Araponga, comentava sobre o controle difícil da voz e do "nervosismo" quando teve que aprender a "falar em reunião" [no contexto de sua iniciação em reuniões como representante da aldeia que tem seu pai como cacique].

No que diz respeito à definição de posições de autoridade em diferentes níveis - desde o âmbito familiar, mais ou menos estendido, ao aldeão - a feição da liderança parece bastante variável, a depender de estilos pessoais e das fases de constituição de um coletivo, e não haveria também um modo particular de "fala do chefe" ou contextos que lhe confeririam um lugar predeterminado. Nem praça ou reuniões masculinas para decisões; posições de liderança aqui, mesmo para um cacique, precisam ser conquistadas. E a habilidade para falar é certamente um lugar privilegiado de construção de autoridade e prestígio.

Na base, a liderança de um "pessoal" (um coletivo) por um homem ou um casal tem sempre a constituição de um grupo mais ou menos numeroso de parentes consanguíneos e afins que vêm se juntar a eles, mas a feição da liderança pode variar bastante. Assim, a autoridade de um líder local pode ligar-se ao reconhecimento de sua capacidade de sabedoria e orientação enquanto "pajé" ou "líder carismático", modo que foi tido por autores como Nimuendaju (1987 [1914]:76) e Schaden(1962:99-100) como a forma tradicional da chefia guarani. Pode, ainda, compor com outras posições de liderança local, afastando-se ou aproximando-se da autoridade xamânica, ou produzindo distinções como a política dentro da aldeia e as representações desta nas relações com outras aldeias e negociações com jurua (brancos).

Diferenças nos modos de fala usados por líderes acompanham as variações de contextos e dos estilos pessoais. É interessante notar, neste sentido, que, se idealmente um chefe guarani deve ser próximo de um xamã ou guia espiritual que domina a fala bonita e que aconselha de modo brando, isto não anula a presença, em certos contextos, de um discurso afirmativo de autoridade, destoante da ética do comedimento. Augustinho, cacique e xamã - com sua esposa, Marciana - em Araponga, vez ou outra afirmava enfaticamente, diante de visitantes no pátio que em 
"sua aldeia [tinha] lei", do mesmo modo como teria sido no tempo dos "antigos". No comentário sobre a liderança em algumas aldeias, encontramos mesmo a figura de uma "polícia" dos caciques, muitas vezes descrita como um grupo de jovens xondáro ${ }^{11}$ que lhe daria apoio na solução de situações como a de buscar alguém que tenha fugido para outra aldeia para lhe prestar contas.

De todo modo, investidas como esta nos fazem lembrar constantemente a figura da chefia vazia de poder descrita por Clastres(1974a). Efetivamente, nada pode o cacique em face da decisão daquele que saiu e não quer voltar, mesmo em relação a seus próprios descendentes quando venham a manifestar desejos de autonomia. Como diria Clastres (1974a), o poder do chefe tem o seu lugar, mas não tem capacidade de fazer valer a vontade do chefe, nem mesmo quando este apresenta sua polícia. De fato, na melhor das hipóteses, a autoridade de um cacique se revela como capacidade de constituir - e manter o quanto possível junto de si - um pessoal que não se dispersa facilmente. Para isso, nada como aprender a "falar bem". E, claro (continuando aqui com Clastres), ser generoso na distribuição de recursos que venham a estar sob seu controle.

Se a ausência de falas de comando revelam, afinal, a falta de poder dos líderes locais, por outro lado, há alguma expectativa, por parte daqueles que ficam junto de um cacique ou de alguém em vias de se tornar um, de sua disposição de mediação, pela fala, em situações como as de conflitos entre moradores locais. O comentário de pessoas que se queixam dos caciques afirmando o desejo de abandonar uma aldeia pode apontar tanto para o excesso quanto para a ausência completa das palavras do chefe. "Não falar nada", isto é, não se posicionar para a solução de uma dada questão, ou falar de modo impositivo leva no final das contas, ao mesmo lugar, isto é, ao desejo propriamente de deixar o lugar.

Fausto (2001:276) observa um paradoxo entre os Parakanã: se, por um lado, há uma resistência às palavras de comando e mesmo à elevação de voz, por outro lado é possível que em certos contextos se sinta falta de uma fala com capacidade exortativa. Minha impressão nas aldeias mbya é que a fala do cacique, em sua capacidade de mover disposições, se liga antes à sabedoria que se lhe atribui e à sua capacidade de pacificar conflitos internos à comunidade ${ }^{12}$ do que à exortação para atividades coletivas ${ }^{13}$.

Ainda que não possamos aprofundar aqui uma análise sobre chefia ou liderança (que caberia melhor tomar no plural)mbya, vale apontar os insights preciosos de Perrone-Moisés (2015) sobre como a função-chefe diz respeito antes a uma relação (não hierárquica, mas assimétrica) do que a uma singularidade, e sobre a compreensão do chefe "puxador de movimento"como um "subcaso da função-anfitriã" que a autora elabora tomando a festa como matriz relacional ameríndia (em par com a guerra). 
Nas últimas décadas, para além de lugar importante de construção do carisma e autoridade diante daqueles que vivem em uma mesma aldeia, a fala de lideranças, seja a proferida pelo cacique ou por outros homens e mulheres adultos, assume o papel crucial de fazer a política com - e contra - os brancos, tema que não poderei desenvolver aqui, e que certamente nos levaria à abordagem de modos contemporâneos de articulação entre política e xamanismo entre os Guarani e Kaiowa, principalmente a partir dos anos 1980, bem como a novos estilos vocais ${ }^{14}$.

Voltando ao contexto da fala elaborada que remete ao saber dos antigos e à relação com as divindades, e também ao tema dos deslocamentos, cabe ainda um paralelo com a etnografia parakanã. Se a exortação da fala de quem lidera se liga, no contexto parakanã, à disposição para a guerra e a caça, pondo em foco o chefe guerreiro e o xamã (ou propriamente o "telescópio xamânico" capaz de saber onde encontrar presas [Fausto 2001:277]), o casombya coloca em relação-ação a pré-visãoxamânica e a procura renovada de lugares para se viver e fortalecer a condição de vivente. Como na migração dos antigos, aquele que "vai na frente" é o que "vê" ou "escuta" primeiro e "conta". Falar e levar, palavra e movimento, sempre entrelaçados ${ }^{15}$.

Aqui nos aproximamos de uma outra dimensão da fala e do movimento. Quem fala bem, ou ainda, como veremos, canta bem (e possivelmente desenvolve outras capacidades da oralidade, como a cura soprando e fazendo mover doenças com tabaco) tende a manter consigo - ou atrair - pessoas que se dispõem a ficar sob sua orientação. Falar bem, afinal, tem eficácia terapêutica.

\section{Cantar}

Se a charada de Ilda com que abrimos este texto remete à força e ao movimento da palavra, não há momento de maior intensidade nesta fusão que o da reunião na reza. Aqui a palavra é levada ao máximo de sua potência, virando canto e dança.

Na opy, a reza se faz por meio de falas emocionadas que os xamãs rezadores ou rezadoras dirigem aos deuses, e no canto de alguns donos e donas de mboraei (a forma mais elaborada de canto-reza mbya), acompanhados por coro de vozes e danças em uníssono que se formam ali mesmo, com mulheres, crianças, rapazes que se levantam e se juntam no centro da casa.

A "concentração" para a reza se faz aos poucos, com a marcação de um mbaraka (violão mbya de cinco cordas que marca o ritmo) nas mãos de um rapaz sentado em um dos cantos da casa, e as frases do rave (rabeca 
mbya) que um companheiro executa a seu lado. No acúmulo da fumaça do petyngua que vai preenchendo o espaço, a fala vem se juntar aos instrumentos, tornando-se canto; o som ganha intensidade.

Esse início da reza nos lembra o que Anthony Seeger (2015) propõe para a abordagem da música como parte de um conjunto maior, cultural, de formas expressivas vocais. Seeger demonstra, etnografando os gêneros vocais suyá, como a abordagem comparativa de aspectos da estrutura formal e outros nos permitem aprofundar a compreensão das diferentes formas vocais e do lugar da música na cultura. Uma abordagem próxima à de Seeger de dois gêneros musicais guarani - jeroky e yvyrai 'ja - presentes em aldeias nhandeva e kaiowá, foi realizada por Montardo (2009). Chamorro (2011) analisou três formas da "palavra cantada" kaiowá e seus contextos - ñembo'e, guahu e kotyhu - como parte de uma pesquisa mais ampla sobre formas musicais guarani. Stein (2009), em sua pesquisa etnomusicológica, analisou forma, centro tonal e desenvolvimento de motivos em dois gêneros mbya infantis, relacionando-os aos mborai xamânicos. Observo que meu comentário aqui estará restrito à música feita nas sessões rituais na opy, mas uma análise sistemática das expressões musiciais mbya nos levaria a outras formas, como as performances de pátio e a um gênero contemporâneo que recebe grande investimento, que é a música feita para apresentações em coral a públicos não indígenas e reuniões com participação de diversas aldeias.

Etnógrafos com experiência com grupos tupi-guarani apontaram o lugar marcante da expressão sonora nestes grupos, que impacta qualquer pesquisadora ou pesquisador quando se depara com sua intensidade. Com os Guarani não é diferente. Quando a noite vem chegando, o som toma o lugar, e vai ganhando força na reunião de pessoas que vão entrando na opy para se juntar à reza.

Antes de virem as palavras, enfumaça-se a casa. Como noutros contextos de xamanismo ameríndio, a palavra aqui se torna potente em conexão com outros actantes, notadamente o tabaco e os instrumentos musicais. Há variações nos modos de fazer a reza e também quanto à presença na opy de puxadores de canto ou de participantes de modo geral, que poderiam vir a compor o coro. As disposições variam, podendo haver maior ou menor elaboração na música, na presença de instrumentos e duração da sessão. De todo modo, é possível reconhecer uma sequência bastante regular. O xamã ou outro rezador levanta-se com seu mbaraka e começa uma reza-canto, de início apenas com a marcação rítmica do mbaraka colado ao peito, acrescentando adiante sua voz nas frases cantadas. Havendo disposição, faz-se acompanhar de um coro de canto-dança de mulheres e rapazes. Elas com seus takuapu (taquara de dança) e eles executando o mbarakamiri (chocalho). 
Mais que falar às divindades, trata-se aqui de fazer uso mesmo do modo vocal dos deuses. Pois, como observou Viveiros de Castro para o xamanismo dos Araweté (1986) e Fausto para os Parakanã (2001), os deuses não falam, eles cantam. A música na opy não é outra coisa senão a própria expressão do que se ouve do alto (yvate), de nhanderukuéry (coletivo de divindades), e neste sentido, experiência imediata de escuta-fala. Isto com a intensidade que se sente no corpo, pois que canto e dança são, como observou Montardo(2009:141), partes de uma mesma linguagem.

Se os cantos levantados na opy originam-se de uma escuta pessoal, feita em sonho ou vigília por parte dos que se tornam seus donos, tal qual lemos em vários relatos etnográficos ${ }^{16}$, por outro lado, como observou Nimuendajuno caso da dona do mboraei ensinado em sonho pelo pai falecido (Nimuendaju 1987 [1914]:77-78), o importante é executá-los. É nesse momento que os cantos parecem entrar efetivamente em ação ou, poderíamos dizer, que sua força age: no instante em que se tornam fluxo de palavra que não para, linguagem que efetivamente conecta deuses e humanos. Aqui o sentido do comentário que ouvi de muitos participantes da reza na opyde Araponga, que cheguei a frequentar diariamente: é nhanderukuéryque "faz descer" (-mboguejy) ali mesmo os mboraei ${ }^{17}$.

Os cantos descem do alto para simultaneamente subirem, pois sua execução visa levantá-los ao máximo, para que os mesmos pais e mães celestes possam ouvi-los. Daí um grande investimento: busca-se virtuosismo, beleza e intensidade. O coro eleva as vozes uma oitava acima das frases do puxador do mboraei;mantém notável afinação e harmoniza-se com o movimento dos corpos unidos pelos braços entrelaçados, taquaras simultâneas contra o chão. O mesmo empenho e harmonia desse coro feminino de vozes e takuapu vemos entre os tocadores de mbarakamiri e na performance de quem puxa o canto. A potência na voz, como a que alcança Marciana em noites de reza na aldeia Araponga, é apreciada e valorizada em sua "força" por diversos visitantes destaopy.

Se a música tem potência em si mesma, como indicam nossos sentidos quando participamos da reza-canto guarani, a dança a intensifica. Entre os muitos modos de agenciar as palavras divinas usados pelas pessoas mbya, nenhum deles parece se igualar em intensidade à reunião para cantar e dançar na opy. Nenhum comedimento nesse fluxo de palavras, pelo contrário, a disposição para o canto-dança deve ser levada ao máximo. Somos encorajados a levantar e compor o coro, a permanecer na dança, e a sentir afinal a potência da música na própria disposição física, no corpo que ganha leveza, no estado de ânimo "alegre" que sentimos. Após um tempo no mboraei, a repetição das frases cantadas e dançadas em saltos, a aceleração do ritmo 
nos instrumentos e corpos consonantes, o acúmulo do tabaco que invade os sentidos, tudo isso costuma fazer alguém cair em desmaio enquanto dança e "queimar" no "fogo de nhanderu" ali mesmo, limpando todo tipo de doença ou mal que por ventura carregue.

Ao ficarmos alegres na dança afastamos a doença (ou seus indícios). É este o efeito da música e da dança na reza mbya: mbaraete, fortalecimento da condição de vivente. Ao serem questionados, os xamãs, as rezadoras e os rezadores sempre dizem que se faz a reza "para ficar alegre" e "todos ficarem com saúde", ou ainda "não acontecer nada a ninguém (nenhuma morte)". Trate-se de rituais elaborados como os nhemongaraifeitos para se ouvirem os nomes divinos das crianças, cerimônias associadas frequentemente ao cultivo do milho avaxiete ou à erva mate, o ka'a, ou da reza-canto cotidiana, o ritual tem sempre caráter profilático-curativo. A afirmação de que é "para todos" indicaria ainda que a potência do canto estende seus efeitos para além dos que se levantam efetivamente para cantar e dançar.

"Individualismo" e "coletivismo" foram apontados por Schaden (1962:110, 147-148)como dois aspectos do xamanismo guarani nos seguintes termos. De um lado, cada pessoa poderia "entrar em contato com o sobrenatural", tendo "experiências religiosas próprias" (Schaden 1962:110); de outro lado, o "religioso" definiria justamente o sentido das principais "manifestações [...] da existência comunitária" (:110). O próprio ritual pode assumir muitas feições, como observou o autor, desde a reza particular de alguém que a canta de sua própria casa até o ritual reunindo toda uma comunidade.

Uma outra maneira de interpretar estas facetas, a meu ver, poderia nos levar à compreensão da potência xamânica como capacidade (disponível, em princípio, a toda pessoa enquanto portadora de nhe'ë) que, sendo efetuada, sempre produz efeitos para aqueles que lhe são relacionados. Sentar na opy (sem participar diretamente do canto-dança) é já um modo de se fortalecer, como me disse uma vez o cacique Miguel em Parati Mirim. Sentir-se bem, ficar alegre dançando e cantando no meio da casa é experimentar no corpo o que o ritual faz. Por outro lado, essa potência, maximizada pela música cantada e dançada ao longo de horas por um grupo de pessoas, é capaz de propagar seus efeitos na extensão da própria humanidade (mbya) espalhada pelos diversos "fogos" (tataypy) na Terra ${ }^{18}$. Menos que duas facetas do ritual xamânico guarani, minha sugestão, talvez demasiado simples, é a de que, ao efetuar a "sua" reza, quem canta estende necessariamente seus efeitos sobre quem é capaz de escutá-la. 


\section{Palavra e movimento}

É bastante conhecida na literatura clássica sobre grupos Guarani a afirmação da palavra como fundamento do ser, imagem que se concentra principalmente no aspecto divino da pessoa humana ("verdadeira", ou seja, guarani) e na qualidade divina de palavras ditas "belas", "boas", igualmente "verdadeiras", que devem animar a vida dos coletivos guarani na Terra. Muito frequentemente esta imagem se liga à percepção da religião ou religiosidade como definidora de uma identidade cultural guarani e da história de sua resiliência. A palavra nesta perspectiva coincide com os termos nhe'ë, palavra-nome (alma-palavra, alma-nome) de origem divina, e ayvuporã , "fala bonita" ou "linguagem religiosa" (Cadogan 1992:36), palavras que os deuses comunicam aos que se dedicam à reza. Seja como marcadora da origem e do destino divinos dos humanos - isto é, aqueles filhos e filhas cujos nhe'ë foram enviados de regiões celestes e, após a morte, retornarão a elas - seja como instrumento da comunicação com as divindades e da transmissão de conhecimentos-capacidades para a vida na Terra - referida aqui como nhe'ëporã ou ayvuporã , é sempre "palavra divina".

\section{Conclusão}

O breve sobrevoo neste texto sobre práticas vocais mbya em contextos e modos distintos de pôr a palavra em ação nos levou a outros lugares igualmente fundamentais do agir das palavras. Assim, para além da conexão entre os Guarani e seus pais e mães divinos, parece interessante perceber o que a palavra é capaz de fazer e desfazer entre humanos.

Instrumento e meio da construção do parentesco, da constituição de autoridade e do fazer político, ela todo o tempo põe em movimento os humanos. Cria suspeitas ou conflitos, fazendo ir embora parentes; pode enviar doença ou mesmo matar quando agenciada como "fala feia" ou feitiçaria. Com a mesma potência pode criar adesões, fazendo com que se vá atrás de um parente que "fala bem", que sabe contar o que ouviu dos antigos e guardou na cabeça. Ou ainda, é capaz de produzir saúde e boas disposições, quando se torna fala bonita e poética feita na língua dos deuses, em frases alongadas.

Os contextos focalizados nos exigiriam aprofundamento na análise dos conteúdos e das estruturas formais, na abordagem das performances, na compreensão do ritual. Vou me restringir, contudo, a um único ponto que me parece fundamental. Trata-se de reconhecer a força da palavra como 
potência de movimento. Para dizer do modo mais simples: palavras sempre fazem mover. Mas o interesse aqui é justamente perseguir e aprofundar sentidos desse mover(-se), a começar pelos deslocamentos espaciais.

Este não seria absolutamente um aspecto desconhecido na literatura sobre grupos Guarani. Pelo contrário, esta junção estaria, como já referido, na base dos profetismos tupi e guarani, conforme o interpretaram Hélène e Pierre Clastres (Clastres,H. 1978 [1975]; Clastres,P. 1975), aos quais voltaremos adiante. As palavras dos grandes xamãs ou profetas seriam o motor de extensos movimentos migratórios à procura da "terra sem mal", como os descritos nos século XVI e XVII (Métraux 1927), e em certos contextos no século XX (Nimuendaju 1978 [1914]; Schaden 1962; Ciccarone 2001; Mendes Júnior 2016, entre outros).

Deslocamentos no espaço continuam se desdobrando dos usos bonitos ou feios da palavra, como pudemos ver ao focalizar a etnografia mbya. Mais ou menos extensos nos espaços que percorrem e nos corpos que envolvem(correspondente ora a saídas de pessoas em visitas, fugas, expulsões, ora a cisões maiores em aldeias), continuam a mobilizar a procura de lugares ${ }^{19}$. Como dizem nossos próprios interlocutores mbya, "o Guarani não para". Se o tema da busca por yvymarãe'ÿ parece ocupar, no cotidiano atual de muitas aldeias, uma outra intensidade que aquela presente nos contextos das antigas migrações, o não parar atual define antes a busca por saúde, pelo viver bem, pelo ficar alegre.

O movimento no espaço, ainda que contido pelas tantas "cercas" postas pelos brancos, impeditivas de um modo econômico-ecológico conhecido pelos mais velhos, adaptado à configuração das aldeias estabelecidas em Terras Indígenas e aos novos modos de circulação entre parentes, continua efetivamente. E, mesmo com os constrangimentos presentes, expande um território multilocal (Instituto Socioambiental 2016).

Mas a potência da palavra como movimento estaria também presente numa outra forma de produzir saúde e alegria: no movimento intensivo dos corpos no canto-dança na reza. Aqui palavra e movimento não se distinguem. Pelo contrário, se fundem na atividade corporal, assim como o espaço e o tempo, já que a força da palavra cantada não implica qualquer distância. Tudo acontece ali mesmo ${ }^{20}$.

Pensar a palavra-fala-canto guarani em suas dimensões extensiva e intensiva nos lembra a sugestão de Pierre Clastres sobre a transformação que ela teria experimentado no curso da história. No texto Le grandparler (Clastres, P. 1974b, na versão em português traduzido como "A fala sagrada" em 1990),Clastres sugere que a palavra guarani teria se "interiorizado" enquanto metafísica, perdendo sua dimensão prática de orientação para 
as migrações em busca de yvymarãe'y̆, "terra sem mal" ou "das coisas não mortais". De uma "busca" anteriormente feita no espaço, os Guarani teriam passado a uma "espera no tempo", o caminho de divinização tornando-se principalmente objeto de uma reflexão profunda sobre a condição humana que se quer superar. Esse processo seria lido pelo autor como passagem do mito ao logos (Clastres, P. 1990:12-13).

HélèneClastres (1978 [1975]), ao analisar a procura da "terra sem mal" enquanto tema central dos profetismos tupi-guarani, e o que nomeia de ascese guarani, aprofunda a ideia de um espaço nãoterritorial, "destinado apenas a ser percorrido" (Clastres, H.1978 [1975]:66), espaço que se faz equivaler a "tempo necessário para se consumar a lenta mutação dos espíritos e dos corpos [...]" que tornaria os humanos capazes de "ascender ao término de sua busca". Mutação, como sugere, passando pelo abandono das normas sociais, pela renúncia a todas as atividades que têm lugar nas aldeias.

Para além da análise de movimentos proféticos que persistiriam desde antes do encontro com o cristianismo até o século $\mathrm{XX}$, é de um pensamento que a autora está se ocupando, que se expressa nesses movimentos e também numa percepção da pessoa humana em sua ambiguidade. Um pensamento, no final das contas, contra a coerção: "o pensamento da Terra sem Mal não se reduz [...] ao pensamento de um Alhures estritamente espacial. Trata-se de pensar um Outro do homem, absolutamente isento de coerção; homem-Deus" (Clastres, H. 1978 [1975]:68).

Como observou recentemente Renato Sztutman ao comentar "o encontro dos Clastres com os Guarani" (Sztutman2018), o que P. Clastres teria desenvolvido a partir do diálogo com sábios guarani em Le grand parler (1974b) seria uma espécie de "versão filosófica ou metafísica de um problema que até então se revelava [para aquele autor] de maneira mais sociológica" (Sztutman 2018:212), isto é, na abordagem da questão da concentração de poder pelos chefes e da guerra ameríndia. Seguindo Sztutman, o "contra-Estado" da tese de P.Clastres da "sociedade contra o Estado" (Clastres, P. 1974a) tomaria, em Le grand parler (Clastres, P. 1974b), o sentido do "contra-Um".

Nesta direção, o profetismo seria, na interpretação de H.Clastres, um movimento de resistência à sociedade enquanto unificação, e uma busca de superação da ambivalência da condição humana, submetida, de um lado, ao regime de "doença" e "estrago" (tekoaxy) que caracteriza a vida na Terra e, de outro lado, dotada de um aspecto divino (palavra-nome-canto, que faz "levantar"), ao ser potencializado com vistas à maturação físico-espiritual, aguyje, assemelhando-se à condição divina. Humanidade submetida ao tekoaxy, tempo da vida social tido como "tempo da prova" (Clastres, H. 1978:108), quando esses habitantes de yvymba'emeguã ("terra imperfeita") 
nascem, reproduzem-se e morrem (como parte que são da animalidade). Humanidade "eleita" para alcançar o estado incorruptível próprio dos deuses. Separados homens e deuses, o pensamento da "terra sem mal" traria como valor ético a noção de que homens e deuses não estariam definitivamente separados.

O que me interessa reter principalmente das análises de H. e P.Clastres neste momento é a revelação, por esses autores, de uma metafísica outra, ameríndia (ou propriamente guarani), como tem reconhecido Renato Sztutman, ou as conexões fundamentais entre o pensamento de Pierre Clastres do "contra o Estado" com as "metafísicas da predação" e o multinaturalismo (e perspectivismo) ameríndio, conforme desenvolve Viveiros de Castro (1996, 2009, 2010, entre outros).

Voltemos ao texto de P.Clastres com foco nas "belas palavras" dos sábios guarani ${ }^{21}$, menos para as hipóteses clastreianas sobre mudanças na longa duração, e mais para a percepção de Clastres sobre esta metafísica outra. Como observou Sztutman, trata-se da inauguração do diálogo entre pensamento ocidental e pensamento ameríndio (ou guarani), este último revelando sua potência de crítica à lógica ocidental da identidade do Ser fundada no princípio da não contradição. A partir da análise de mitos e exegeses xamânicas, P.Clastres reconhece afinal no pensamento guarani o que designa como a negação do Um (ou do Múltiplo unificado na Unidade do Ser). Resistindo à lógica identitária, os Guarani fariam a escolha pelo Dois - escolha que, entendendo a possibilidade de coexistência entre o humano e o divino na pessoa guarani, orientaria as práticas com vistas ao aguyje, alcançado tanto pela via da busca espacial de yvymarãey quanto através do canto-dança na reza.

Em um texto de 2013, Renato Sztutman chama a atenção para o caráter de recusa do poder coercitivo do pensamento ameríndio, e guarani em particular, associando a metafísica guarani revelada por Clastres a um evento contemporâneo de resistência, por parte dos Kaiowa, à expulsão de suas terras em Mato Grosso do Sul. Impedidos de se movimentarem em liberdade no território em que viviam desse modo noutros tempos, contidos por um longo processo de "confinamento"(Brand 1997) que, contudo, não os paralisou - como podemos observar nos movimentos de retomada de seus lugares de habitar - os Kaiowa vêm dizer em público suas palavras que resistem à lógica do ser ou não ser, da submissão ou fim. Dizem: "Sabemos que seremos expulsos daqui da margem do rio pela Justiça, porém não vamos sair da margem do rio" (Kaiowa 2012). Diante do despacho da Justiça Federal de Navirai, em Mato Grosso do Sul, que os obrigava a sair daquele local, afirmaram que ficariam e morreriam ali mesmo, afirmação que produziu 
grande repercussão nas redes sociais, sendo lida por muitos como ameaça de um suicídio coletivo.

Sztutman, contudo, nos sugere que se trata antes da "recusa existencial de viver num mundo em que não há lugar para outros mundos que não aqueles baseados no desenvolvimento econômico e no poder do capital [...]" (Sztutman 2013:167). Recusa do Um, incapaz de abarcar possibilidades outras. Recusa de um pensamento que não admite a contradição.

O que a etnografia mbya contemporânea nos deixa ver repetidamente, me parece, é a presença de uma atividade que não cessa. Pessoas e coletivos insistem em mover-se no espaço, reinventar modos de não parar. Ao contrário daquela impressão que P.Clastres teve num dado momento, a metafísica aqui mantém-se colada na práxis ou na cosmopráxis da não sujeição - ou da liberdade,como disse Sztutman ${ }^{22}$.

Pesquisas recentes com foco nas formas políticas ou cosmopolíticas guarani apontam nessa direção, e têm afirmado o movimento como condição fundamental da existência - ou da coexistência (incluindo outras humanidades, não guarani) - na Terra. A vida entre parentes implica, como vimos, movimento. Na experiência pessoal, pode ser mesmo insuportável ficar parado, como, por exemplo, nas reservas kaiowá (Pimentel 2012:137). O não parar, que entre os Guarani assumiu constantemente a feição de deslocamento espacial, não deixa de ser movimento de alterar seguidamente contextos de vida e a si mesmo, atividade sempre voltada à produção de diferença. Um dos modos de abordagem dessa produção de diferença permitiu uma reaproximação com o tema lévi-straussiano do "dualismo em perpétuo desequilíbrio", cuja potencialidade analíticavem sendo explorada por Perrone-Moisés (2006, 2015, entre outros; Perrone-Moisés \& Sztutman 2009), e que Pierri (2012) buscou aplicar ao par complementar perecível-imperecível na cosmologia guarani.

Outro enfoque recente foi a abordagem do movimento da "esquiva", tomado da dançambya ao modo da capoeira feita pelo xondáro - como altamente produtivo para pensar a relação no modo político mbya, que pode ser descrito como modo "que não submete tampoucodeixa se submeter" (Santos2017). Políticas de manter a diferença, sem se render à perspectiva do Outro nas relações com alteridades, feitas de "aberturas e fechamentos" (Prates 2013).Um modo de não abrir mão de "outras alegrias", como aquelas experimentadas na embriaguez, que levam ao limite mínimo a distância entre vivos e mortos, em processos de alteração que Heurich (2011) analisa à luz dacauinagemameríndia. Enfim, movimento que nega a identidade, que insiste em alterar ou, conforme a expressão de Mendonça (2009), que se faz propriamente "contra o estável". Sem o que, afinal, não há alegria de qualquer espécie. 
A etnografia contemporânea guarani tem chamado a atenção para o lugar central da alegria na vida desses coletivos(Pissolato 2007; Heurich 2011; Pimentel 2012; Pereira 2014; Aranha 2018, entre outros). Ainda que o viver bem-de maneira bonita(tekoporã) se desenhe no contraste com estragos que seriam próprios à vida na Terra, longe de negar esta experiência, mobiliza forças repetidamente para a produção de saúde e de novas alegrias, disposição que continua seligando estreitamente às andanças por lugares, ao dançar ea outras formas de alterar e mover os corpos. Pensamento que recusa o desânimo, palavras que não cessam de agir.

Recebido em: 01 de outubro de 2019.

Aprovado em: 28 de fevereiro de 2020.

Elizabeth Pissolato

Etnóloga, pesquisadora e professora no Programa de Pós-Graduação em Ciências Sociais e Departamento de Ciências Sociais da Universidade Federal de Juiz de Fora, Minas Gerais. Desde 2001 dedica-se à pesquisa em etnologia guarani, com especial interesse em dimensões do parentesco, corpo e emoções, mobilidade e multilocalidade, cosmologia, ontologia, cosmopolíticas em suas variações guarani.

https://orcid.org/0000-0001-5330-1788

E-mail: elizabeth.pissolato@gmail.com 


\section{Notas}

Agradeço a leitura atenta e as sugestões generosas dos pareceristas deste artigo, que dedico a Ivanildes Kerexu, e a seu caminho bonito e promissor de aprendizado na palavra.

1 Os termos extensivo e intensivo devem ser lidos aqui não em chave deleuziana, mas em seus significados na língua portuguesa: extensivo como aquilo que produz extensão, que se amplia (no caso, movimento que envolve simultaneamente ou em tempos distintos muitas pessoas e tende a se estender por espaços ainda não ocupados), e intensivo como o que tem intensidade, visa alcançar eficácia por meio de esforço intenso (no caso, o movimento concentrado em uma sessão de canto-dança).

2 Este texto toma por base minha pesquisa com pessoas que viviam (muitas delas ainda vivem) em aldeias guarani no litoral fluminense conhecidas como pertencentes ao subgrupo mbya, com trabalho de campo concentrado nos anos de 2001 a 2009, bem como em pesquisas de colegas antropólogos e antropólogas desenvolvidas principalmente nos últimos vinte anos nestas e em outras aldeias no sudeste e sul do país, além de no Pará e Tocantins (v. referências ao final do texto). Mas se o foco é na etnografia produzida principalmente em contextos mbya, a intenção é buscar, mesmo que modestamente, aproximações com a pesquisa desenvolvida junto aos Kaiowá e Guarani concentrados no Mato Grosso do Sul, sem perder de vista, ainda, o diálogo com abordagens que permanecem instigantes de autores como Nimuendaju (1987[1914]), Schaden (1962), H.Clastres (1978) e P. Clastres (19974a,1990[1974b]).

3 Ainda que nhe'ë enquanto "fala", "verbalização" compreenda um espectro mais amplo (além da fala humana ou palavras dos deuses, o canto de aves, outras verbalizações animais, o som de flautas etc), tais interpretações se baseiam na definição já referida de nhe'ë como alma-palavra ou palavra-nome que marcaria o vínculo - do nascimento à morte - entre humanos (Guarani) e seus pais e mães divinos. Este vínculo está na base tanto de uma interpretação da pessoa guarani (com ênfase sobre seu aspecto divino) quanto da relação "religiosa" entre humanos e deuses, marcada pela proteção que os Guarani receberiam em vida de seus pais e mães celestes, dos quais, por sua vez, não devem jamais se esquecer, fazendo-lhes sempre o canto-reza. É importante notar, por outro lado, que Montoya (1985[1639]:52-55) já apontava a "eloquência no falar" entre os Guarani e seus efeitos sociais, como o de "agregar gente e vassalos".

4 Ao tratar destas dimensões identificamos diversas formas vocais (como gêneros de fala e canto), que mereceriam maior atenção. Não invisto, contudo, em qualquer análise sistemática destas formas, preferindo inclusive não marcar fronteiras precisas entre elas, seja porque me faltam elementos e competência para uma análise mais rigorosa, ou ainda por me parecer interessante destacar a continuidade entre as mesmas.

5 Veja-se, entre outros, o lugar central da conversa no contexto do trabalho cotidiano entre os Pa'ikwené (Palikur) (Passes 2000:97-113), e a concepção embera de "pessoas falando junto" como a condição efetiva da produção de sociedade (Isacsson 1993 apud Passes 2000:103). 
6 Como observou Nimuendaju (1985:31-32), "o nome [...] é, a bem dizer, um pedaço do seu portador, ou mesmo quase idêntico a ele, inseparável da pessoa [...]. O fato de malbaratar o nome pode prejudicar gravemente seu portador". O ponto é reforçado em várias etnografias contemporâneas (Bartolomé 1991:85; Mendes Júnior 2016:56-57, entre outros).

7 A comunicação entre parentes e os deslocamentos (quando se vai atrás de parentes) são temas presentes já no mito dos heróis fundadores guarani. Kuaray vai atrás do pai quando ainda é um feto no ventre de sua mãe. Sua capacidade xamânica permite-lhe a comunicação com a mãe e a indicação correta do caminho para a casa do pai. A comunicação se interrompe quando ele se aborrece com a mãe irritada com seus pedidos (e com uma picada de mamangava), ausência de comunicação que justamente a levará a ser devorada, pois chega à casa dos jaguares. Da mesma forma uma irritação e um desentendimento anterior com a esposa teriam feito o pai de Kuaray ir embora, deixando a Terra.

8 Compare-se o "ir junto" ou "ir atrás" guarani com o modo do parentesco dos Piro nas palavras de Peter Gow (1997:56): o gwashlu, "viver bem", valor supremo para os Piro, corresponderia efetivamente ao "morar e não fazer mais nada". O termo remeteria à "tranqüilidade do dia a dia da vida na aldeia, a uma vida marcada pela ausência de qualquer tristeza, insatisfação ou ressentimento que leve uma pessoa a querer se mudar".

9 O tema que se tornou conhecido como a "busca da Terra sem Mal" ou "terra onde não mais se morre" (Nimuendaju 1987[1914]:9,15) foi retomado por muitos autores após o texto de Nimuendaju. Não será possível aqui tomá-lo em análise, mas retornaremos a ele adiante para um comentário da tese de Clastres sobre as "belas palavras" guarani. Quanto aos registros de movimentos migratórios, veja-se Nimuendaju (1987[1914]:8-10; 62-64) para a migração dos Tañyguá, que saem do Paraguai em 1810, até sua fixação na Serra de Itatins; e também sobre as migrações apapocúvas(:11-15) por volta de 1870, em sua "marcha para o leste". Para o século XX, vejam-se, entre outros,os relatos de Schaden (1962:12-13) para grupos que se deslocaram, entre as décadas de 1920 e 1940, para o litoral de São Paulo; a tese deCiccarone (2001) para a migração empreendida pela prestigiosa xamã Tataxï, que chega ao Espírito Santo na década de 1960; e, mais recentemente, a tese de Mendes Júnior (2016), que retoma o tema e analisa a migração de um grupo guarani que sai da fronteira paraguaia nos anos 1930 e chega até o entorno da cidade de Mozarlândia, Goiás, na década de 1960.

10 Podemos dizer que as narrativas referidas de modo geral como "histórias dos antigos" compreendem tanto passagens míticas de Kuaray e Jaxy, relatos do fim da Primeira Terra e surgimento da atual após dilúvio, feitos dos grandes xamãs do passado quanto narrativas sobre eventos envolvendo antepassados (referidos de modo coletivo como "avós") que chegaram a ser vistos/ouvidos ou dos quais se ouviu falar por parentes mais velhos. Minha impressão é a de que particularmente as narrativas que costumamos chamar de míticas produzem grande concentração na escuta mesmo por parte de crianças bem pequenas.

11 Xondáro, corruptela da palavra "soldado", define um estilo de dança-luta (conforme dizem alguns rapazes guarani, "parecida com capoeira") feita tanto nas opy quanto em pátios, sendo também um modo de referência para quem toma parte nela, assumindo a forma xondária no feminino. O termo se estende, fora do contexto 
da dança, a rapazes colaboradores de um cacique que podem ser mobilizados por este em contextos, por exemplo, de conflitos envolvendo moradores locais, relações com aldeias vizinhas, em ações em face dos brancos etc. Mendonça (2009:113-118) descreve como se dava o treinamento de antigos xondáro, sua relação com "a força de um animal" na busca de qualidades ideiais de caçadores, guerreiros, guardiões. Tais treinos poderiam levá-los "a uma leveza do corpo "[tornando-os] quase invisíveis na mata" (:114). A autora propõe ainda xondáro como disposição que pode ser experimentada no "interior de cada pessoa", em relação disjuntiva com uma outra disposição, tamõi, associada ao xamã (:127-128). Santos (2017) parte da dança do xondáro e aprofunda a figura da "esquiva" para chegar a uma abordagem de formas políticas entre os Guarani contemporâneos.

12 Nem sempre a fala do cacique aqui se faz como aconselhamento, conversa. Em certas situações, como no caso de visitantes cuja presença e comportamento sejam sentidos como prejudiciais a alguém que tenha prestígio suficiente junto ao cacique para fazê-lo, é possível que a este seja demandado que "mande embora" o recém-chegado. Comentários de situações deste tipo acenam sempre para o mandar embora como modo de evitar a radicalização do conflito, isto é, com agressão física ou homicídio.

13 Em outro artigo (Pissolato 2016) observei a resistência em relação ao que se chama "trabalhar para o cacique" em aldeias mbya. Parece haver aqui uma tensão entre um modo econômico que tende a definir como unidade de produção as famílias nucleares ou casais enquanto se mantém - em algum grau - a aldeia como unidade política. Tomando a forma ameríndia da reciprocidade entre a palavra generosa do chefe ("o dom das palavras" [Fausto 2001:224]) e a sua liberação de atividades produtivas, podemos dizer que, nas aldeias mbya contemporâneas, só em contextos especiais o cacique ocupa a posição de quem recebe produtos do trabalho dos outros.

14 A tese de Spensy Pimentel (2012) sobre o fazer político kaiowa e guarani, e particularmente sua etnografia sobre as assembleias AtyGuasu em Mato Grosso do Sul e sobre os contextos de ocupação de terras onde viveram e das quais foram expulsos, apresenta uma análise cuidadosa da articulação entre política e xamanismo, demonstrando a centralidade do discurso político-profético e do canto-reza, o JerosyGuasu, nas ações coletivas empreendidas na luta pela terra. Estilos novos de cantos que não se desvinculam do fazer político guarani e kaiowa foram igualmente tratados em pesquisas nas últimas décadas. Macedo (2009:177189) descreve e analisa um modo de apresentação da cultura que ganhou adesão geral após os anos 1990 entre os Mbya. Há a formação de corais e a produção de um repertório característico por cada aldeia, para apresentações em contextos festivos, sejam nas próprias aldeias, em reuniões guarani mais amplas, ou em eventos nas cidades promovidos por secretarias de cultura, universidades, prefeituras etc. Por sua vez, outras formas musicais, como o rap, vêm sendo mobilizadas em manifestações étnicas e políticas por jovens guarani e kaiowá na relação com os brancos e as cidades. Assim, há rappers como os Bro-MCs, que mesclam o português e o guarani para falar das condições precárias, violentas da vida nas reservas kaiowá na região de Dourados, MS (Carvalho 2018), bem como vozes que vêm ganhando espaço nas assembleias Aty Guasu de Mulheres e de Jovens desde 2012 no Mato Grosso do Sul, além de falas-(e)-cantos que se difundem em redes sociais e marchas públicas, inaugurando novas formas de reflexividade e de resistência. 
15 O contexto das migrações guarani atestaria o que Viveiros de Castro observou como "dependência total" da palavra do xamã entre os Tupi-Guarani, como diz o autor, enquanto "vidente-ouvinte do Além"(Viveiros de Castro 1986:64-65). Neste sentido, Mendes Júnior (2016:165) observa como o grupo Guarani que iniciou migração na década de 1930 a partir do Paraguai rumo ao norte brasileiro, motivado tanto pela "busca da perfeição físico-espiritual" quanto pela guerra do Chaco, interrompe o empreendimento com a morte de seu último xamã nos anos 1960. Mas cabe notar os dois aspectos do xamanismo guarani: de um lado, a presença prestigiosa de dirigentes do canto-reza, dos que curam com tabaco e são capazes de ver em sonho o que está em vias de acontecer e, por isso mesmo, levam consigo um grupo de parentes e, de outro, a possibilidade da dúvida sobre os diagnósticos xamânicos. Note-se a presença na etnografia guarani de temas como o do "acreditar" (ou não) nas palavras de um xamã para a tomada de decisões, no tratamento de doenças ou na confirmação do nome pessoal. Como entre os Araweté, é certo que haverá diversidade de versões xamânicas quando são diversos os xamãs (Viveiros de Castro 1986:64).

16 O veículo da recepção de cantos é quase sempre o sonho, mas há quem entenda também que nhanderukuéry possam fazê-los descer imediatamente no contexto da reza-canto. Há alguma variação nas etnografias quanto a quem poderia enviá-los. Nimuendaju (1987[1914]:77-78) traz exemplos da recepção de cantos ensinados por parentes mortos. Para Schaden (1962:123), os cantos são "presentes dos deuses ou espíritos [...] transmitidos através do sonho". A xamã kaiowá Dona Odulia contou a Montardo (2009:55-56) que teria recebido enquanto dormia o "canto da copa das árvores" de um homem adornado (55-56).

17 O mboraei, enquanto forma musical, pode ser contrastado com a fala elaborada em metáforas na "língua da opy". Aqui, na música que conecta imediatamente e em fluxo contínuo deuses e humanos, o "texto" quase desaparece. É o ritmo e o trabalho melódico sobre as notas, alongadas na voz do coro, que ganham elaboração. Schaden(1962:122) já teria notado, em seu comentário sobre o porahêi, que "o importante [não seria] o sentido das palavras [...], mas o seu poder evocativo [...] do sentimento religioso [...]". Enfim, palavras aqui, antes de tudo, efetuadas.

18 Um comentário alternativo sobre tais efeitos afirma que a própria vida da Terra dependeria de o canto e a dança continuarem (Meliá, Grünberg \& Grünberg 1976; Montardo 2009).

19 Sobre a mobilidade nos grupos guarani contemporâneos, a qual Mendes Júnior (2016:164) sugere definir em contraste com a migração [voltada à busca da terra sem mal]),noto que a etnografia contemporânea tendeu a complexificar e colocar em diálogo a dimensão "religiosa" - e mesmo o tema da "busca de yvymarãe'ÿ" com outros aspectos presentes na movimentação de pessoas e coletivos, como fatores ecológicos, trocas econômicas, matrimoniais, cerimoniais etc, conflitos locais ou interétnicos, guerras, expulsões etc. Veja-se, entre outros, Meliá (1990),Garlet (1997), Ladeira (2001), Mello (2006).

20 Diferentemente de contextos pessoais ou interpessoais, em que as falas bonitas ou feias tendem a produzir efeitos ao longo de um tempo e/ou a certa distância no espaço, como, por exemplo, no caso da feitiçaria (Chase-Sardi 1992:94-97; Pissolato 2007:198-211). 
21 Renato Sztutman faz um comentário cuidadoso da coletânea "Le grand parler" no artigo já referido (Sztutman 2018), coletânea que reúne textos bastante diversos entre si, incluindo narrativas míticas, textos de caráter esotérico, reflexões livres desdobradas destas narrativas porsábios guarani. Discutindo a proposição de Clastres sobre a passagem do mito ao logos,Sztutman reconhece certo caráter evolucionista, o mito sendo tomado aí como momento que antecede a reflexão pelo sujeito no desenvolvimento do pensamento. Contra isso sugere, inspirado em Perrone-Moisés (2011), a não separação entre mito e logos e a percepção da mitologia como fundo de virtualidades, a narrativa mítica sendo entendida como discurso aberto. Não acompanharei de modo sistemático o comentário de Sztutman, que explora o diálogo deste com outros trabalhos de Pierre e Hélène Clastres.

22 Renato Sztutman, articulando as análises de Clastres sobre guerra e chefia ameríndia às figuras da "máquina de guerra" de Deleuze e Guattarri (2004[1980]) e ao "dualismo em perpétuo desequilíbrio" em História de Lince (Lévi-Strauss 1993[1991]), frisa a potência libertária da metafísica canibal que Clastres antevê. Irredutível ao "ser",tal metafísica, para além de negar um pensamento identitário de modo passivo, fariauma escolha de manter em atividade aliberdade. 


\section{Referências bibliográficas}

ARANHA, Aline de Oliveira. 2018. Inspirações sobre o fazer(-se) polític@ entre os Guarani-Mbya. Dissertação de Mestrado, USP.

BARTOLOMÉ, Miguel Alberto. 1991. Chamanismo y religion entre los Ava-Katu-Ete. Assunción: Centro de Estudos Antropológicos.

BRAND, Antônio. 1997. O impacto da perda da terra sobre a tradiçãokaiowál Guarani:os difíceis caminhos da palavra. Tese de Doutorado, Pontifícia Universidade Católica de Porto Alegre.

CADOGAN, León. 1959. Ayvu Rapyta: Textos míticos de los Mbyá-Guaraní del Guairá. São Paulo: Boletim 227, Antropologia 5, Faculdade de Filosofia, Letras e Ciências Humanas da Universidade de São Paulo. 1992. Diccionario Mbya-Guarani - Castellano. Asunción: Biblioteca Paraguaya de Antropología/Fundación LeonCadogan/ Ceaduc-Cepag.

CARVALHO, Rodrigo A. 2018. Rimas de Si, Batidas de Outrem -estratégias de visibilidade e regimes de alteridade dentre os rappers kaiowá (Reserva Indígena de Dourados/RS). Tese de Doutorado, PPGAS, Museu Nacional, UFRJ.

CHAMORRO, Graciela. 1995. KurusuÑë'engatu: palabras que la historia no podría olvidar. Asunción: Centro de Estudios Antropológicos. .1998. A espiritualidadeGuaraní: uma teologia ameríndia da palavra. São Leopoldo: Sinodal.

2011. "A arte da palavra cantada na etnia kaiowa". Bulletin - Société Suisse des Américanistes, 73:43-60.

CHASE-SARDI, Miguel. 1991. El Precio de la Sangre: TugüyNeëRepy. Estudio de la Cultura y el Control social entre los Avá-Guaraní. Asunción: Centro de Estudos Antropológicos.
CICCARONE, Celeste. 2001. Drama e sensibilidade. Migração, Xamanismo e Mulheres Mbya Guarani. Tesede Doutorado em Ciências Sociais, Pontifícia Universidade de São Paulo.

CLASTRES, Hélène. 1978 [1975]. Terra sem mal: o profetismo Tupi-Guarani. São Paulo: Brasiliense.

CLASTRES, Pierre. 1974 a. La sociétécontrel'Etat. Paris:LesÉditions de Minuit. 1990 [1974b]. A fala sagrada: mitos e cantos sagrados dos índiosGuarani. Campinas/São Paulo: Papirus.

COURSE, Magnus. 2011. "O nascimentoda Palavra: linguagem, força e autoridade ritual Mapuche". Revista de Antropologia, 54 (2):781-827.

DELEUZE, Gilles \& GUATTARI, Felix. 2004[1980]. Mil platôs: capitalismo e esquizofrenia.(Vol.2).São Paulo: Editora 34.

FAUSTO, Carlos. 2001. InimigosFiéis: história, guerra, xamanismo na Amazônia. São Paulo: Edusp.

GARLET, Ivori J. 1997. Mobilidade Mbya: história e significação. Dissertação de Mestrado, PUCRS.

GOW, Peter. 1997. "O parentesco como consciência humana: o Caso dos Piro". Mana, 3 (2):39-65.

HEURICH, Guilherme Orlandini. 2011. Outras alegrias: respeito e embriaguez mbya. Dissertação de Mestrado, PPGAS/UFRJ.

INSTITUTO SOCIOAMBIENTAL. 2016. Mapa Guarani Continental. Campo Grande: Ed. Equipe Mapa Guarani Continental.

ISAACSON, Suen-Erik 1993 Transformations of Eternity: On Man and Cosmos in Emberá Thought. PhD Dissertation, Göteborg University. 
KAIOWÁ GUARANI. 2012. Carta-manifesto de setembro de 2012. Disponível em:http://desinformemonos. org/2012/10/decretemnossa-morte-coletiva-e-nos enterrem-todos-aqui-dizem-guarani-kaiowa-da-comunidade-de-pyeblito-kue/. Acesso em 07/08/2019.

KELLY, Jose A. 2017. "On yanomami ceremonial dialogues: a political aesthetic of metaphorical agency". Journal de la Société des Américanistes, 103(1):179-214.

KOPENAWA, Davi \& ALBERT, Bruce. 2015 [2010]. A queda do céu: palavras de um xamã yanomami. São Paulo: Cosac e Naify.

LADEIRA, Maria Inês. 2007[1992]. O caminhar sob a luz. O território mbya à beira do oceano. São Paulo: Unesp. . 2001. Espaço Geográfico Guarani Mbya: significado, constituição e uso. Tese de Doutorado em Geografia, Universidade de São Paulo.

LÉVI-STRAUSS, Claude. 1993[1991]. História de Lince. São Paulo: Companhia das Letras.

MACEDO, Valéria M. 2009. Nexos da diferença. Cultura e afecção em uma aldeia guarani na Serra do Mar. Tese de Doutorado, PPGAS-FFLCH, USP.

MELLO, Flávia Cristina de. 2006. Aetchánhanderukuerykarairetarã: Entre deuses e animais: xamanismo, parentesco e transformação entre os Chiripá e Mbyá Guarani. Tese de Doutorado, UFSC.

MELIÀ, Bartomeu. 1990. "A Terra sem Mal dos Guarani: Economia e Profecia". Revista de Antropologia, 33:33-46.

MELIÁ, Bartomeu; GRÜNBERG, Georg \& GRÜNBERG, Friedl. 1976. "Etnografia GuaranídelParaguayContemporaneo: Los Pai-Tavyterã". Suplemento Antropologico,Asunción, XI, n.1-2:151-295.
MENDES JÚNIOR, Rafael. 2016. A saga rumo ao norte e os outros do caminho: a busca da terra sem mal entre os Guarani contemporâneos. Tese de Doutorado, PPGAS, Museu Nacional, UFRJ.

MÉTRAUX, Alfred. 1927. "Lesmigrationshistoriquesdes Tupi-Guarani". Journal de la Société des Américanistes, 19:1-45.

MONTARDO, Deise Lucy O. 2009. Através do mbaraka: música, dança e xamanismo Guarani. São Paulo: Edusp.

MONTOYA, Pe. Antonio Ruiz de. 1985[1639]. Conquista Espiritual feita pelos religiosos da Companhia de Jesusnas Provincias do Paraguai, Paraná, Uruguai e Tapé. Porto Alegre: MartinsLivreiro.

NIMUENDAJU, Curt U. 1987 [1914]. As lendas de criação e destruição do mundo como fundamentos da religião dos Apapocúva-Guarani. São Paulo: Hucitec/ Edusp.

OVERING, Joana. 1991. "A Estética da Produção: O Senso de Comunidade entre os Cubeo e os Piaroa". Revista de Antropologia, São Paulo, n.34:7-33.

OVERING, Joana \& PASSES, Alan (eds.). 2000. The Anthropology of Love and Anger, The Aestheics of Conviviality in Native Amazonia. London: Routledge.

PASSES, Alan. 2000. "The value of working and speaking together". A facet of Pa'ikwené (Palikur) conviviality". In: Joanna Overing \& Alan Passes (eds.),The Anthropology of Love and Anger. The Aestheics of Conviviality in Native Amazonia. London: Routledge. pp. 97-113.

PEREIRA, Vicente Cretton. 2014.Aqueles que não vemos: uma etnografia das relações de alteridade entre os Mbya Guarani. Tese de Doutorado em Antropologia, Universidade Federal Fluminense. 
PERRONE-MOISÉS, Beatriz. 2006. "Mitos Ameríndios e o Princípio da Diferença". In: Adauto Novaes (ed.), Oito Visões da América Latina. São Paulo: Senac. pp. 241-257. 2011. "Bons chefes, maus chefes, chefões: elementos de filosofia política ameríndia". Revista de Antropologia: 857-883. . 2015. Festa e guerra. Tese de Livre-docência, Universidade de São Paulo.

PERRONE-MOISÉS, Beatriz \& SZTUTMAN, Renato. 2009. "Dualismo em perpétuo desequilíbrio: desafios ameríndios". Anais. São Paulo: Anpocs.

PIMENTEL, Spensy K. 2012. Elementos para uma teoria política kaiowá e guarani. Tese de Doutorado em Antropologia, Universidade de São Paulo.

PIERRI, Daniel Calazans. 2013. O perecível e o imperecível: lógica do sensível e corporalidade no pensamento Guarani-Mbya. Dissertação de Mestrado, USP.

PISSOLATO, Elizabeth. 2007. A duração da pessoa: mobilidade, parentesco e xamanismo mbya (guarani). São Paulo: Edunesp.

. 2015. "Fuga como estratégia: notas sobre sexualidade, parentesco e emoções entre pessoas mbya". Cadernos de Campo: 412-426. . 2016. "Trabalho, subsistência e dinheiro: modos criativos na economía mbya contemporânea". Horizontes Antropológicos, 45:105-125.

PRATES, Maria Paula. 2013. Da instabilidade e dos afetos: pacificando relações, amansando Outros. Cosmopolítica guarani-mbya. Tese de Doutorado, UFRGS.
SANTOS, Lucas Keese. 2017. A esquiva do xondaro - movimento e ação política entre os Guarani Mbya. Dissertação de Mestrado, USP.

SCHADEN, Egon. 1962. Aspectos Fundamentais da Cultura Guarani. São Paulo: EPU/Edusp.

SEEGER, Anthony. 2015[1997]. Por que cantam os Kisëdjë: uma antropologia musical de um povoamazônico. São Paulo: Cosac e Naify.

STEIN, Marília Raquel Albornoz. 2009. Kyringüémboraí: os cantos das crianças e a cosmo-sônica Mbyá-Guarani. Tese de Doutorado em Música, UFRGS.

SZTUTMAN, Renato. 2013. "A potência da recusa - algumas lições ameríndias". Sala Preta, v. 13 (1):163-182.

2018. "O desabrochar da palavra". In: D. Gallois \& V.Macedo (orgs.), Nas redes Guarani. Saberes, traduções, transformações. São Paulo: Hedra.

SURRALÉS, Alexandre. 2003. "Face to face : meaning, feeling and perception in amazonian welcoming cerimonies". Journal of Royal Anthropological Institute, n.s.9 :775-791.

VIVEIROS DE CASTRO, Eduardo. 1986. Araweté: os deuses canibais. Rio de Janeiro: Anpocs/Jorge Zahar Editor.

1996. "Os pronomes cosmológicos e o perspectivismo ameríndio". Mana, 2 (2):115-144.

. 2009. MétaphysiquesCannibales. Paris: Puf. . 2010. "The untimely, again". In: Pierre Clastres, Archeology of violence, New York: Semiotext(e). 


\section{PALAVRA E(M) MOVIMENTO: FORMAS VOCAIS EM ALDEIAS GUARANI}

\begin{abstract}
Resumo
Tomando por base a etnografia contemporânea com grupos GuaraniMbya, este texto pretende tecer um comentário sobre modos diversos de uso da palavra em contextos interpessoais e de reunião nas aldeias, entendendo-os, conforme a sugestão de Anthony Seeger, como parte de uma mesma arte vocal guarani. Menos que uma análise sistemática das formas vocais, o foco aqui recai sobre o agir da palavra, seja falada, cantada ou silenciada. Seguindo desdobramentos diversos da palavra em diferentes contextos nas aldeias, sugerimos que sua potência se efetua propriamente como movimento, seja extensivo (pessoas-corpos que se deslocam no espaço), seja intensivo (movendo corpos na dança) ${ }^{1}$. O diálogo com proposições de Pierre e HélèneClastres sobre transformações da palavra guarani, inspirado por sugestões recentes de Renato Sztutman, nos leva, ao final do texto, à definição do movimento enquanto potência de não sujeição ou de liberdade.
\end{abstract}

Palavras-chave: Guarani, Mbya, Palavra, Gêneros vocais, Movimento.

\section{PALABRA Y/EN MOVIMIENTO: FORMAS VOCALES EN ALDEAS GUARANÍ}

\section{Resumen}

Teniendo en cuenta la etnografía contemporánea con grupos GuaraníMbya, se propone tejer un comentario sobre los modos diversos del uso de la palabra en contextos interpersonales y de encuentro en las aldeas, entendiéndolos tal como sugirió Anthony Seeger, como parte del mismo arte vocal guaraní. Menos que un análisis sistemático de las formas vocales, el enfoque aquí está en la actuación de la palabra, así sea hablada, cantada o silenciada. Siguiendo diferentes desarrollos de la palabra en diferentes contextos en las aldeas, sugerimos que su potencia se efectúa realmente como movimiento, ya sea extenso (personas-cuerpos que se mueven en el espacio) o intensivo (cuerpos en movimiento en la danza). El diálogo con las propuestas de Pierre y Hélène Clastres sobre las transformaciones de la palabra guaraní, inspirado en las recientes sugerencias de Renato Sztutman, nos lleva, al final del texto, a la definición del movimiento como un poder de no sujeción o de libertad.

Palabras clave: Guaraní, Mbya, Palabra, Géneros vocales, Movimiento. 


\title{
WORD AND/IN MOVEMENT:
}

VOCAL FORMS IN GUARANI VILLAGES

\begin{abstract}
Based on contemporary ethnography with Guarani Mbya groups, this article describes different forms of the use of the word in interpersonal and village meeting contexts, understanding them, as suggested by Anthony Seeger, as part of a singular Guarani vocal art. Rather than a systematic analysis of vocal forms, my focus here is on the acting of the word, be it spoken, sung or silenced. Following different developments of the word in different contexts in Guarani villages, I suggest that its potency is duly effected as movement, whether extensive (peoplebodies moving in space) or intensive (moving bodies in dance). Discussing the works of Pierre and Hélène Clastres concerning transformations of the Guarani word, and inspired by recent suggestions by Renato Sztutman, I conclude by defining movement as a power of non-subjection or freedom.
\end{abstract}

Keywords: Guarani, Mbya, Word, Vocal genres, Movement. 